Prepared in cooperation with the South Dakota Department of Transportation

\title{
Estimation of Potential Bridge Scour at Bridges on State Routes in South Dakota, 2003-07
}

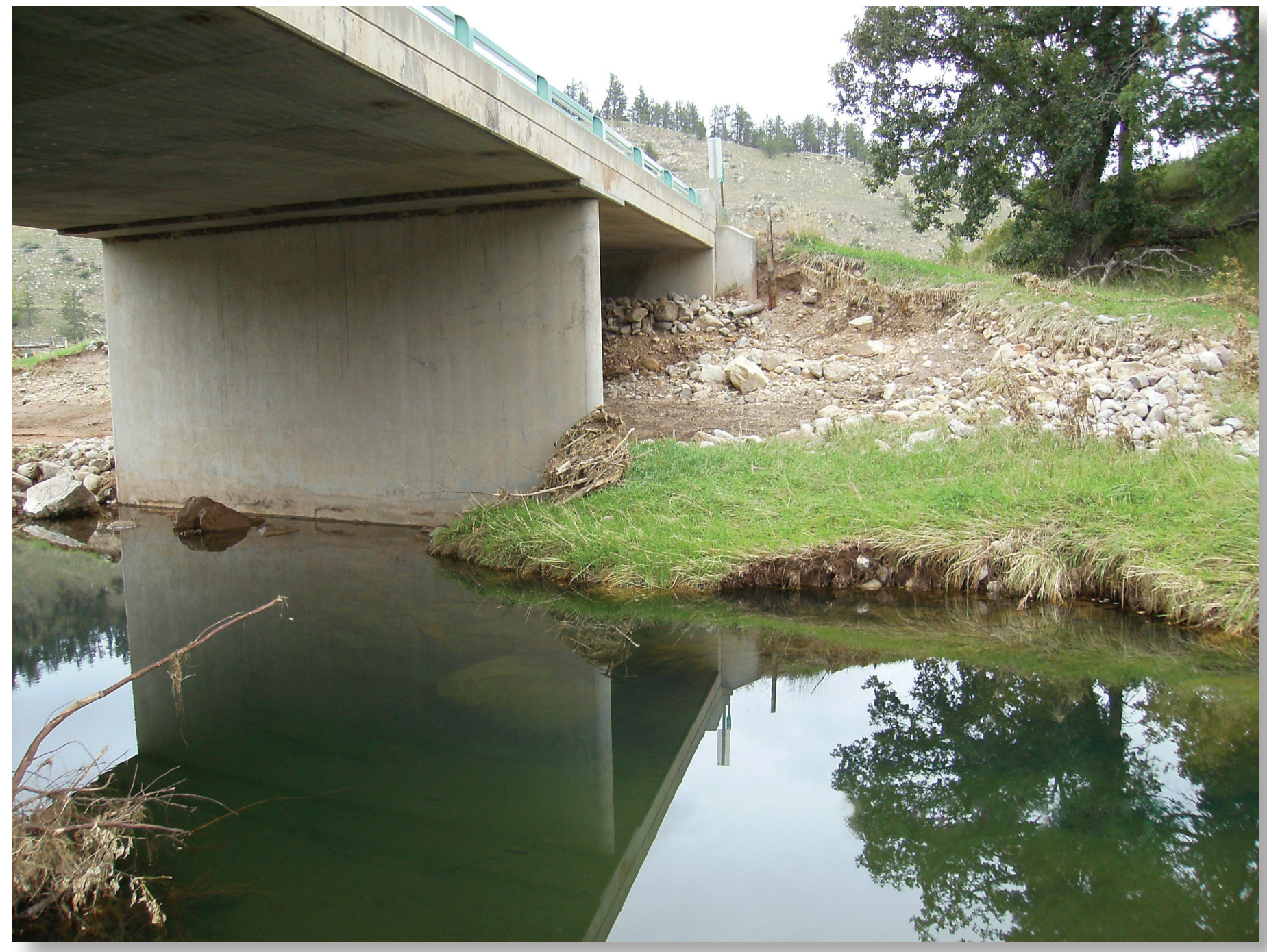

Scientific Investigations Report 2008-5161 
Cover photograph: Contraction scour and abutment scour at the upstream right abutment at a bridge over Battle Creek (structure number 17-408-029) following a flood event in August 2007.

Backcover photograph: Contraction scour under the bridge at Battle Creek (structure number 17-408-029) showing a utility cable and wooden pilings from the previous bridge structure that were exposed by the 2007 flood event. 


\section{Estimation of Potential Bridge Scour at Bridges on State Routes in South Dakota, 2003-07}

By Ryan F. Thompson and Ryan L. Fosness

Prepared in cooperation with the South Dakota Department of Transportation

Scientific Investigations Report 2008-5161 


\title{
U.S. Department of the Interior DIRK KEMPTHORNE, Secretary
}

\author{
U.S. Geological Survey \\ Mark D. Myers, Director
}

U.S. Geological Survey, Reston, Virginia: 2008

For product and ordering information:

World Wide Web: http://www.usgs.gov/pubprod

Telephone: 1-888-ASK-USGS

For more information on the USGS — the Federal source for science about the Earth,

its natural and living resources, natural hazards, and the environment:

World Wide Web: http://www.usgs.gov

Telephone: 1-888-ASK-USGS

Any use of trade, product, or firm names is for descriptive purposes only and does not imply endorsement by the U.S. Government.

Although this report is in the public domain, permission must be secured from the individual copyright owners to reproduce any copyrighted materials contained within this report.

Suggested citation:

Thompson, R.F., and Fosness, R.L., 2008, Estimation of potential bridge scour at bridges on State routes in South Dakota, 2003-07: U.S. Geological Survey Scientific Investigations Report 2008-5161, 18 p. 


\section{Contents}

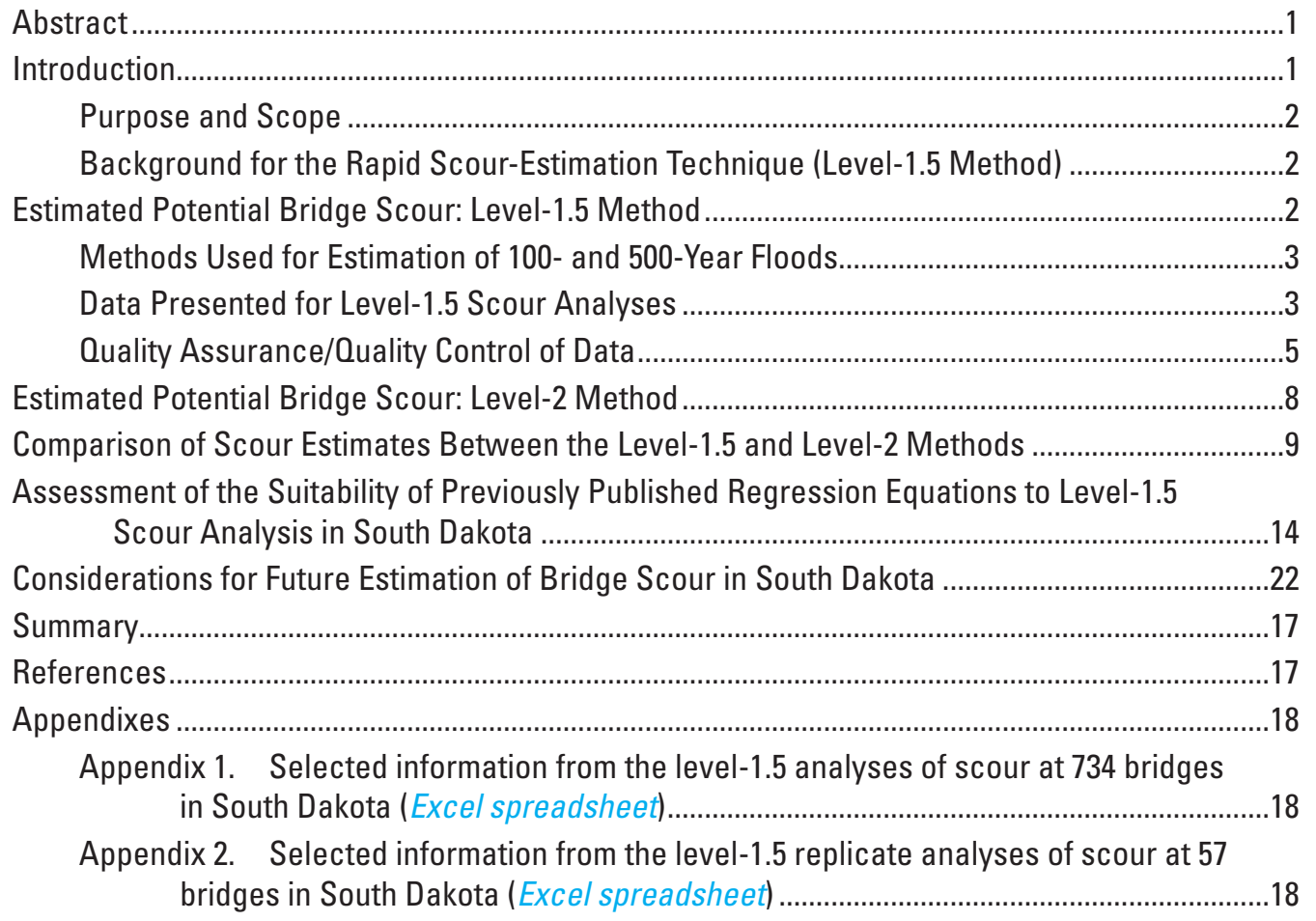

\section{Figures}

1. Locations of selected bridges on State routes in South Dakota visited for level-1.5 scour analyses.

2. Locations of bridges on State routes in South Dakota with replicate level-1.5 scour analyses.

3. Replicate level-1.5 contraction scour estimates...........................................................

4. Replicate level-1.5 abutment scour estimates...........................................................

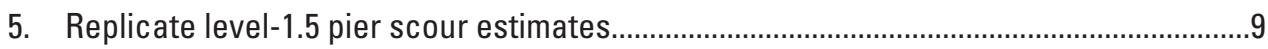

6. Locations of bridges on State routes in South Dakota with level-2 scour analyses.......10

7. Relation of estimated contraction scour between level-1.5 and level-2 analyses..........13

8. Relation of estimated abutment scour between level-1.5 and level-2 analyses .............13

9. Relation of estimated pier scour between level-1.5 and level-2 analyses .......................14

10. Relation between average velocity squared $\left(V_{2}{ }^{2}\right)$ and unit discharge $\left(q_{2}\right)$ for 19 bridges analyzed for this study and 8 bridges analyzed by Niehus (1996)

11. Relation between head loss $(\Delta h)$ through the bridge opening and average velocity squared $\left(V_{2}^{2}\right)$ for bridges analyzed for this study and 11 bridges analyzed by Niehus (1996). 


\section{Tables}

1. Contraction scour estimates from level-1.5 and level-2 analyses, in feet

2. Abutment scour estimates from level-1.5 and level-2 analyses, in feet.

3. Pier scour estimates from level-1.5 and level-2 analyses, in feet.

\section{Conversion Factors}

\begin{tabular}{lcl}
\hline Multiply & By & To obtain \\
\hline foot $(\mathrm{ft})$ & Length & \\
\hline & 0.3048 & meter $(\mathrm{m})$ \\
\hline square foot $\left(\mathrm{ft}^{2}\right)$ & Area & \\
square foot $\left(\mathrm{ft}^{2}\right)$ & 929.0 & square centimeter $\left(\mathrm{cm}^{2}\right)$ \\
square mile $\left(\mathrm{mi}^{2}\right)$ & 0.09290 & square meter $\left(\mathrm{m}^{2}\right)$ \\
& 2.590 & square kilometer $\left(\mathrm{km}^{2}\right)$ \\
\hline cubic foot per second $(\mathrm{ft} / \mathrm{s})$ & Flow rate & \\
\hline
\end{tabular}

Vertical coordinate information is referenced to the North American Vertical Datum of 1988 (NAVD 88).

Horizontal coordinate information is referenced to the North American Datum of 1983 (NAD 83).

\section{Abbreviations and Acronyms}

$\begin{array}{ll}\Delta h & \text { head loss through bridge opening } \\ K_{1} & \text { abutment shape coefficient } \\ K_{2} & \text { correction factor for flow angle of attack } \\ \mathrm{Q}_{100} & \text { 100-year flood } \\ \mathrm{Q}_{500} & \text { 500-year flood } \\ q_{2} & \text { unit discharge in cubic feet per second per foot-width of main channel at the } \\ & \quad \text { contracted section } \\ V_{2} & \text { average main-channel velocity at the bridge contraction } \\ W_{1} & \text { width of main channel at approach section } \\ y_{l o b} & \text { depth of flow, in feet, in left overbank at approach section } \\ y_{\text {rob }} & \text { depth of flow, in feet, in right overbank at approach section } \\ \text { HIRE } & \text { Hydraulics in the River Environment } \\ \text { SDDOT } & \text { South Dakota Department of Transportation } \\ \text { USGS } & \text { U.S. Geological Survey }\end{array}$




\title{
Estimation of Potential Bridge Scour at Bridges on State Routes in South Dakota, 2003-07
}

\author{
By Ryan F. Thompson and Ryan L. Fosness
}

\section{Abstract}

Flowing water can erode (scour) soils and cause structural failure of a bridge by exposing or undermining bridge foundations (abutments and piers). A rapid scour-estimation technique, known as the level-1.5 method and developed by the U.S. Geological Survey, was used to evaluate potential scour at bridges in South Dakota in a study conducted in cooperation with the South Dakota Department of Transportation. This method was used during 2003-07 to estimate scour for the 100-year and 500-year floods at 734 selected bridges managed by the South Dakota Department of Transportation on State routes in South Dakota.

Scour depths and other parameters estimated from the level-1.5 analyses are presented in tabular form. Estimates of potential contraction scour at the 734 bridges ranged from 0 to 33.9 feet for the 100-year flood and from 0 to 35.8 feet for the 500-year flood. Abutment scour ranged from 0 to 36.9 feet for the 100-year flood and from 0 to 45.9 feet for the 500 -year flood. Pier scour ranged from 0 to 30.8 feet for the 100 -year flood and from 0 to 30.7 feet for the 500 -year flood. The scour depths estimated by using the level-1.5 method can be used by the South Dakota Department of Transportation and others to identify bridges that may be susceptible to scour.

Scour at 19 selected bridges also was estimated by using the level-2 method. Estimates of contraction, abutment, and pier scour calculated by using the level-1.5 and level-2 methods are presented in tabular and graphical formats. Compared to level-2 scour estimates, the level-1.5 method generally overestimated scour as designed, or in a few cases slightly underestimated scour. Results of the level-2 analyses were used to develop regression equations for change in head and average velocity through the bridge opening. These regression equations derived from South Dakota data are compared to similar regression equations derived from Montana and Colorado data. Future level-1.5 scour investigations in South Dakota may benefit from the use of these South Dakota-specific regression equations for estimating change in stream head and average velocity at the bridge.

\section{Introduction}

Flowing water can erode (scour) soils and cause structural failure of a bridge by exposing or undermining bridge foundations (abutments and piers). Scour at bridge abutments and piers has historically been the most common cause of bridge failure within the United States (Butch, 1990). In 1988, the Federal Highway Administration recommended that every bridge over a scourable stream be evaluated as to its vulnerability to scour caused by floods (U.S. Department of Transportation, 1988).

In response to this recommendation, the U.S. Geological Survey (USGS) in cooperation with the South Dakota Department of Transportation (SDDOT), conducted a study (Niehus, 1996) during 1992-95 to assess scour susceptibility at 32 bridges and to measure scour at 13 of these bridges. In order to evaluate additional bridges over scourable streams in South Dakota, USGS scientists planned to investigate and apply a rapid scour-estimation technique (level-1.5 method) developed in Montana (Holnbeck and Parrett, 1996) and conduct additional analyses by using the level-2 method. Approximately 863 SDDOT-owned bridges on State routes are over scourable streams in South Dakota (John Cole, South Dakota Department of Transportation, 2002, written commun.). Approximately 100 of these bridges were built after 1992 and had scour analyses incorporated in the design process or were scheduled to be replaced before completion of the scour analyses in 2007. Of the 763 bridges that remained, several more spanned reservoirs or impounded water bodies and were not well suited to scour analysis with the level-1.5 rapid scour-estimation technique. For this study, the level-1.5 method was used to analyze scour at the remaining 734 bridges. At 57 of these bridges, independent replicate analyses were done by various individuals using the level-1.5 method. Scour at 19 of the 734 bridges also was analyzed by using the level- 2 method, so that results of the two methods (level 1.5 and level 2) could be compared and the suitability of the level-1.5 method could be tested for conditions in South Dakota. 
The level-1.5 analyses include estimates for contraction, abutment, and pier scour. Contraction scour is the general lowering of the channel section due to flow acceleration through the channel constriction caused by the bridge (Niehus, 1996). Contraction scour can occur when the bridge abutments are constructed in the main channel or when the bridge is constructed in the flood plain of the river or stream. The river or stream tends to scour the channel bottom to increase the flow area and consequently decrease the flow velocity. Abutment scour is caused by vortices formed where the flow accelerates around the structure. Pier scour is caused by the pileup of water on the upstream face of the pier and the resultant vortices that remove materials from the base area of the pier structure. The scour depths estimated with the level-1.5 method can be used by the SDDOT and others to identify bridges that may be susceptible to scour.

\section{Purpose and Scope}

The purpose of this report is to present and summarize (1) the potential bridge scour estimates from level-1.5 analyses at 734 bridges owned by the South Dakota Department of Transportation (SDDOT) on State routes in South Dakota, (2) a comparison of scour estimates between level-1.5 and level-2 analyses at 19 bridges, and (3) a comparison of the velocity and head loss regression equations derived from results of the level- 2 method for 19 bridges in this study and the 13 level-2 analyses completed by Niehus (1996) to the regression equations of Holnbeck and Parrett (1996). The comparison of level-2 derived velocity and head loss parameters was completed in an effort to determine the suitability of previously published regression equations (Holnbeck and Parrett, 1996) to level-1.5 scour analysis in South Dakota. Considerations for future use of the level-1.5 method to estimate bridge scour in South Dakota also are presented.

The 734 level-1.5 bridge scour analyses for this study were completed during 2003-07, and the 19 level-2 bridge scour analyses were completed in 2007. All these SDDOTowned bridges were on State routes over scourable streams within or on boundary waters of South Dakota.

\section{Background for the Rapid Scour-Estimation Technique (Level-1.5 Method)}

Bridge scour analyses typically are classified as level 1, 2 , or 3, with the increase in level generally indicating a more complex analysis. Level-1 scour analyses are qualitative, general, and based on a visual inspection of the bridge and stream channel including evidence of past scour. Bridge size and geometry data may be either measured onsite or compiled from construction plans. Level-1 scour analyses take several minutes to an hour for one person to complete. Level-2 scour analyses are considerably more complex, and data collected at the site include channel profile and cross-sections, bridge geometry, and properties of the streambed and overbank material. These data are then used in a hydraulics model to calculate flow parameters, such as velocity and depth, that are then used in any of several published scour equations to solve for scour depth. Level-2 scour analyses require a considerable amount of data collection effort and may take 1 or more weeks to complete. Level-3 scour analyses generally are reserved for complex situations or forensic purposes and involve extensive mathematical and physical modeling of the selected bridge.

A rapid scour-estimation technique, known as the level1.5 method, was developed by the USGS for evaluating scour at bridges in Montana (Holnbeck and Parrett, 1996). This method uses limited site data to quantitatively estimate contraction, abutment, and pier scour. One person can complete a level-1.5 analysis in 1 to 3 hours. Although the level-1.5 method is not intended to replace the more detailed level-2 method, it is useful for completing limited-effort analyses that yield a quantitative result.

The level-1.5 method uses a flow estimate (in this study, the 100- and 500-year floods) and bridge dimensions to iteratively estimate a width of flow and resultant depth of flow through the bridge opening. From this estimated flow depth, equations developed from data regression are used to estimate velocity and head loss through the bridge. The depth of flow at the bridge is extended upstream (taking into account head loss) with the use of a hand level to an approach section where flow width and depth are estimated for the main channel and left and right overbank areas. Separate equations are then used to estimate contraction scour, abutment scour, and pier scour, if applicable. The level-1.5 method includes a test for clear-water or live-bed contraction scour conditions and has separate equations for each condition. Clear-water contraction scour conditions occur when the channel velocity is not sufficient to transport bed material, whereas live-bed contraction scour conditions occur when the channel velocity is of sufficient velocity to transport bed material. An envelope curve approach is used so that scour depths tend to be overestimated rather than underestimated. A more detailed description of the level-1.5 method and the derivation of the scour equations used are provided in Holnbeck and Parrett (1996). Because South Dakota did not have a sufficient number of bridge scour analyses completed with the level-2 method to develop a Statespecific set of regression equations for main channel velocity at the bridge contraction or for head loss through the bridge opening, equations 52 and 53, respectively, of Holnbeck and Parrett (1996) were used to compute these parameters.

\section{Estimated Potential Bridge Scour: Level-1.5 Method}

In 2002, there were 863 SDDOT-owned bridges over scourable streams on State routes in South Dakota. Many of these bridges did not require an additional evaluation of scour susceptibility because they were recently built and scour had been a consideration in their design. In addition, other 
bridges were scheduled to be replaced before completion of scour analyses for this study and thus were not evaluated. Of the bridges that remained, some spanned impounded water bodies such as lakes or reservoirs. Because a few of the basic assumptions of the level-1.5 method are not well suited to this situation, impounded sites were not evaluated. Because of long-term dry conditions, however, pool elevations of some of the Missouri River reservoirs were low enough that a few of the normally impounded sites were no longer impounded, and scour at these bridges was analyzed. Additionally, estimating or measuring the necessary variables becomes difficult if water is too deep to wade or the bridge opening is so wide that use of a hand level introduces unacceptable errors. A few additional bridges were excluded because they were too long for application of the level-1.5 method. Figure 1 shows locations of the 734 bridges for which scour analyses were completed by using the level-1.5 method. Location and other information for the 734 bridges is presented in Appendix 1.

\section{Methods Used for Estimation of 100- and 500-Year Floods}

Estimates of the 100-year and 500-year floods were needed for each bridge site that was to be analyzed by using the level-1.5 method. A small percentage of the sites were coincident with streamflow-gaging stations and had readily available flood-frequency statistics. The vast majority of sites, however, had no streamflow data and required estimate computations. Several methods are available for estimating peak-flow frequencies at ungaged sites in South Dakota. Sando (1998) developed a set of regional regression equations to calculate peak flow at various recurrence intervals at ungaged sites. These regression equations were developed from peak-flow data through 1994. Other applicable methods described by Sando (1998) include a method for calculating weighted peak-flow magnitudes for gaging stations, a drainage area-weighting method for ungaged sites on gaged streams, and a weighting method for ungaged sites between two gages on the same stream. The estimation methods described by Sando (1998) have certain limitations related to their source data set and other factors. For example, many of the gaging stations used to develop the regression equations had large drainage areas (greater than 100 square miles). This can lead to greater uncertainties in peak-flow magnitudes calculated for sites with small drainage areas. Additionally, drainage area ratio methods are intended for sites where the ratio of the drainage area of the unknown site relative to the drainage area of the gaging station is between 0.75 and 1.50. In parts of the State with sparse gaging-station coverage, it was not always possible to meet this criterion. Additionally, an updated set of flood frequencies for gaging stations was being developed on the basis of additional peakflow data collected between 1994 and 2001. The updated frequencies based on data through 2001 were published by Sando and others (2008). Early efforts in the flood-frequency update indicated that flood magnitudes for many of the gaging stations had changed notably owing to increases in record length and improvements in the statistical methods used. Thus, in some cases, the existing regional regression equations were not used and alternate methods were used as described in the following paragraph.

A combination of methods was used to estimate the 100- and 500-year floods required for the level-1.5 analyses. Regression equations as published by Sando (1998), or with the updated frequency values (Sando and others, 2008), were used in some cases. The drainage area ratio method was commonly used. In some cases, the drainage area ratio was outside the 0.75 to 1.5 guideline described by Sando (1998). In areas with sparse gaging-station coverage, drainage area ratio methods sometimes were used on adjacent ungaged streams judged to be hydrologically similar to a gaged stream. In cases where a stream had a relief bridge, or where a wide flood plain had multiple streams and bridges that connect during floods, the percentage of the total flow to each bridge was assumed on the basis of the size of the bridge opening and personal judgment. The method used for estimating the 100- and 500-year floods at each bridge site is presented in Appendix 1.

\section{Data Presented for Level-1.5 Scour Analyses}

Data presented for level-1.5 scour analyses at the 734 bridges include contraction, abutment, and pier scour (Appendix 1). The level-1.5 field forms contain comments and diagrams that commonly are essential for interpretation of the estimated scour values. For example, the abutment scour equation for the level-1.5 method (Holnbeck and Parrett, 1996, p. 15) may yield a scour estimate of 5 feet at the left abutment of a given bridge, but comments on the field form may describe existing scour countermeasures, such as riprap or gabion baskets, and indicate that the estimated scour may be partially or completely mitigated. Because it is beyond the scope of this report to include all comments and diagrams recorded on the level-1.5 field forms, selected information from the level-1.5 analyses of scour at each bridge is given in Appendix 1 . Bridges are sorted alphabetically by county and listed in order of structure number within each county. The original level-1.5 field forms, electronic copies of originals, and digital photographs taken at each bridge have been transmitted to the SDDOT for further use. Copies of the field forms are available from the USGS South Dakota Water Science Center, Rapid City, South Dakota, upon request.

Estimates of potential contraction scour at the 734 bridges ranged from 0 to 33.9 feet for the 100-year flood and from 0 to 35.8 feet for the 500-year flood (Appendix 1). Abutment scour ranged from 0 to 36.9 feet for the 100 -year flood and from 0 to 45.9 feet for the 500-year flood. Pier scour ranged from 0 to 30.8 feet for the 100-year flood and from 0 to 30.7 feet for the 500-year flood. The SDDOT compares the scour estimates to foundation depths at each bridge to determine if abutments or piers are at risk of being undermined during a 100- or 500-year flood and can design countermeasures if needed. 


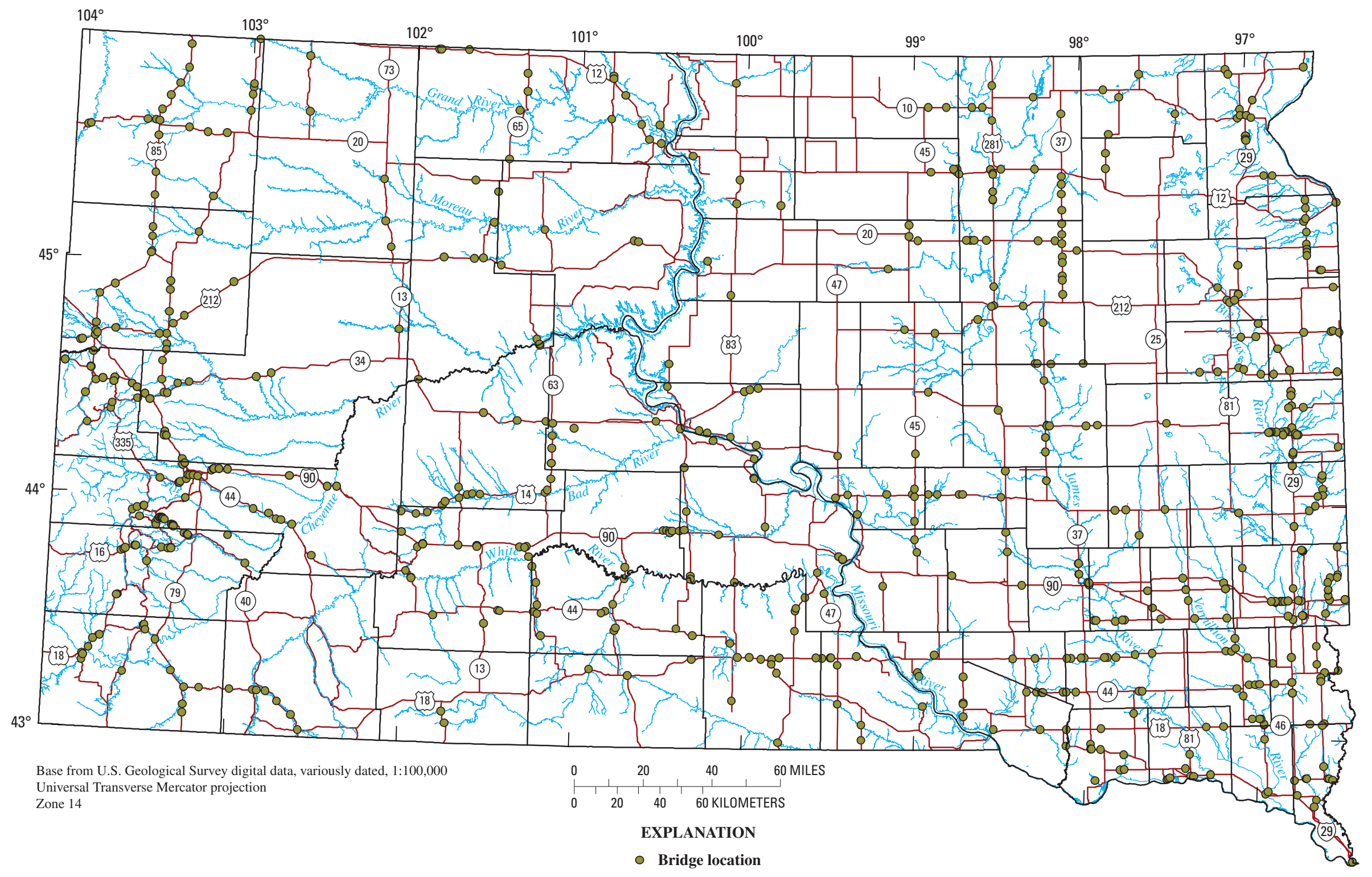

Figure 1. Locations of selected bridges on State routes in South Dakota visited for level-1.5 scour analyses. 


\section{Quality Assurance/Quality Control of Data}

Replicate analyses were made at 57 bridges (approximately 7.8 percent) to provide quality-assurance/quality-control measures for the level-1.5 scour estimates. These analyses were planned when multiple individuals were working in an area at the same time, and additional replicate sites were selected later to provide a better distribution of replicate sites. Replicate analyses were achieved by having different personnel visit the same bridge and independently complete level-1.5 analyses. Four different individuals, identified in Appendix 2 as A, B, $\mathrm{C}$, and $\mathrm{D}$, completed these analyses at the selected bridges. Bridges visited in replicate are shown in figure 2 and listed in Appendix 2. As with Appendix 1, much additional information invaluable to interpreting the results of the replicate scour analyses is given on the field forms. Many of the differences in replicate results presented in the tables in this report can be traced back to one or more different initial assumptions that are explained in the field forms but may not be evident in the information included in Appendix 2. Contraction, pier, and abutment scour estimates from the level-1.5 method each have multiple variables measured or estimated in the field. Small changes in one variable may not affect the estimated scour depths greatly, whereas small changes in another variable may have a large effect. Many factors influence the reproducibility of scour estimates in replicate visits, including channel geometry at and upstream from the bridge and the experience level of the individual completing the analysis. These and other factors are described in the following paragraphs.

Contraction scour has perhaps the greatest potential for being estimated differently in replicate visits. Two of the early steps in completing a level-1.5 contraction scour analysis are estimating the angle at which the 100- and 500-year floods approach the bridge and estimating a point in the bridge opening that represents an average elevation of the channel bottom. In addition to their effect on contraction scour, these two variables also have the potential to affect the estimates for pier and abutment scour. The angle of flow approach sometimes is difficult to estimate because the low-flow channel may intersect the bridge at a substantially different angle than the 100- and 500 -year floods if there is a large amount of overbank flow. The angle of flow approach can affect the effective width of the bridge opening and the effective pier width. The point chosen as the average elevation of the channel bottom is important because it acts as the local datum used to measure overbank flow depths. For bridge sites that have a uniform and flat channel, it is easier to accurately choose an average channel bottom point relative to bridges with very steep or irregular channels or multiple side channels. Replicate contraction scour results do not necessarily have to be in numerical agreement to be similar. For example, if contraction scour replicate estimates are 18.8 feet and 30.8 feet, they both indicate susceptibility to scour for which countermeasures may be needed, even though one number is much greater than the other. Figure 3 provides a scatter plot of replicate contraction scour estimates. A 1:1 trend line indicates where all points would lie if replicates reproduced results exactly. For the contraction scour estimates for the 100-year flood, differences between results from individual A and individuals B, C, or D ranged from 0 to 24.8 feet, with a median difference of 2.9 feet and an average difference of 3.9 feet (Appendix 2). For the 500-year flood, differences ranged from 0 to 18 feet, with a median difference of 4.8 feet and an average difference of 5.5 feet.

Abutment scour appeared to be somewhat more reproducible than contraction scour (fig. 4). The most likely cause of substantial differences among abutment scour replicates is differing estimates of the overbank width or overbank flow depth in the approach section blocked by the abutment at the bridge section. This, in turn, generally is caused by differing elevations chosen as the average location of the channel bottom. At a small number of replicate sites, there was some different interpretation as to which abutment shape coefficient $\left(K_{1} ;\right.$ Holnbeck and Parrett, 1996, p. 16) was appropriate for the abutment, probably because of varying degrees of erosion and previous scour along the abutments under the bridge. For the abutment scour estimates for the 100-year flood, differences between results from individual A and individuals B, C, or $\mathrm{D}$ ranged from 0 to 14.9 feet, with a median difference of 4.0 feet and an average difference of 5.1 feet. For the 500-year flood, differences ranged from 0 to 17.9 feet, with a median difference of 4.3 feet and an average difference of 5.1 feet. As with contraction scour, close numeric agreement of abutment scour replicates is not as important as the magnitude of the scour estimates.

Estimates of pier scour (Appendix 2) were the most consistently reproduced scour estimates in replicate visits, with most points clustered near the 1:1 trend line (fig. 5). Although the velocity and depth of flow at the bridge section are derived from the same procedure required for contraction scour variables, estimated pier scour is not as sensitive to variations in velocity and flow depth as it is to pier size. Differences in replicate pier scour estimates greater than approximately 1 foot are generally the result of differences in assumed flow angle of attack on the pier, which affects the $K_{2}$ correction factor (Holnbeck and Parrett, 1996, p. 10), or differences in estimated pier diameter, such as in cases where water was too deep to physically measure the pier by wading.

For the replicate scour analyses, individual A visited each of the replicate sites, and one or two other individuals (B, C, or D) also visited each replicate site. Because of concurrent work commitments during field seasons, individuals $\mathrm{C}$ and $\mathrm{D}$ only completed a few level-1.5 analyses each year, with most of those being replicate analyses. Individual A completed the bulk of the non-replicate level-1.5 analyses, and rapidly became the most experienced in level-1.5 analysis. Familiarity and degree of experience with applying the level-1.5 method likely play a role in the reproducibility of results among replicate analyses. If the replicate analyses in Appendix 2 were listed in chronological order rather than in order of structure number, a trend of closer agreement of results from individuals $\mathrm{B}, \mathrm{C}$, and D with those of individual A over time would likely be evident. 


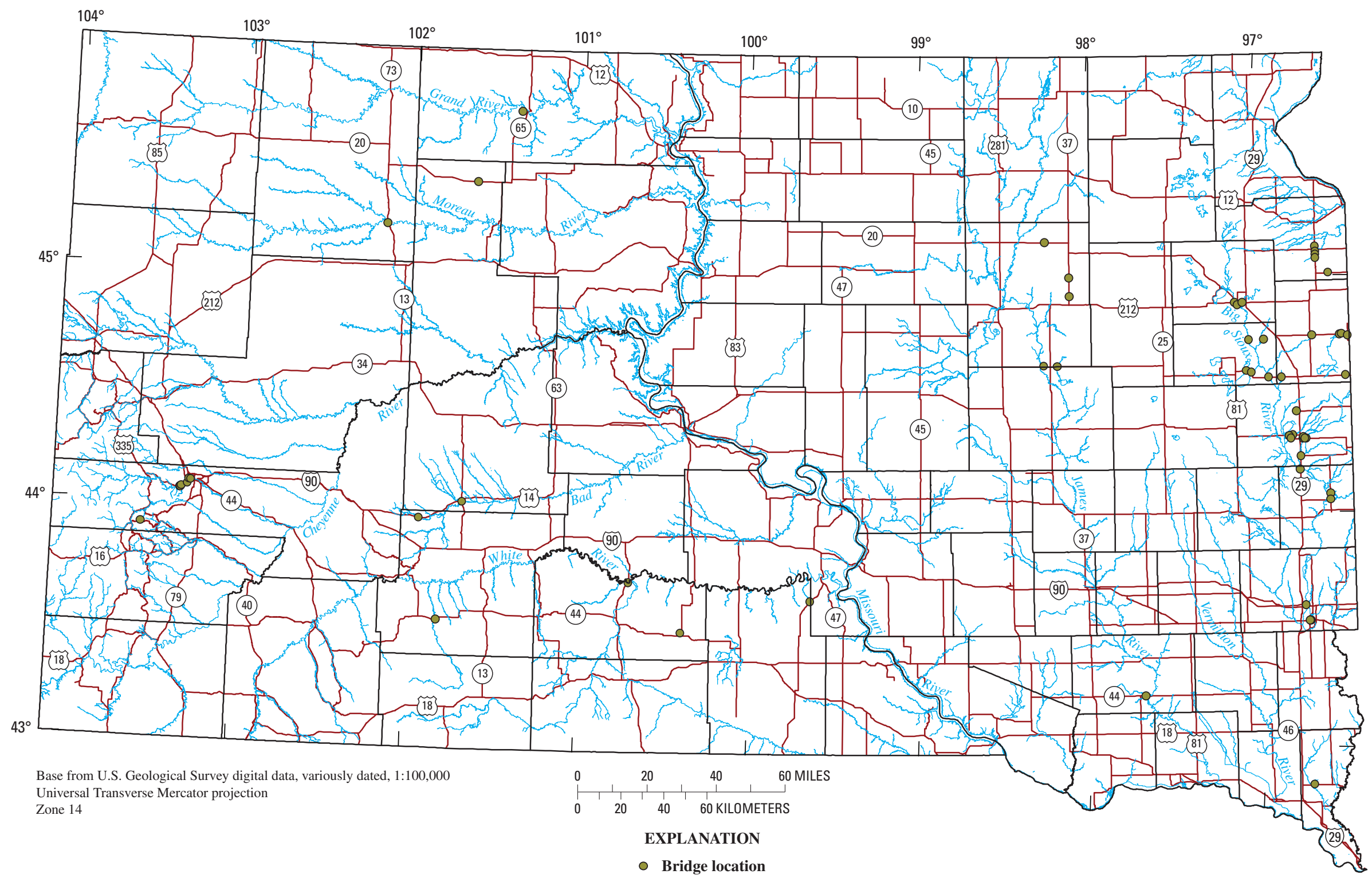

Figure 2. Locations of bridges on State routes in South Dakota with replicate level-1.5 scour analyses. 


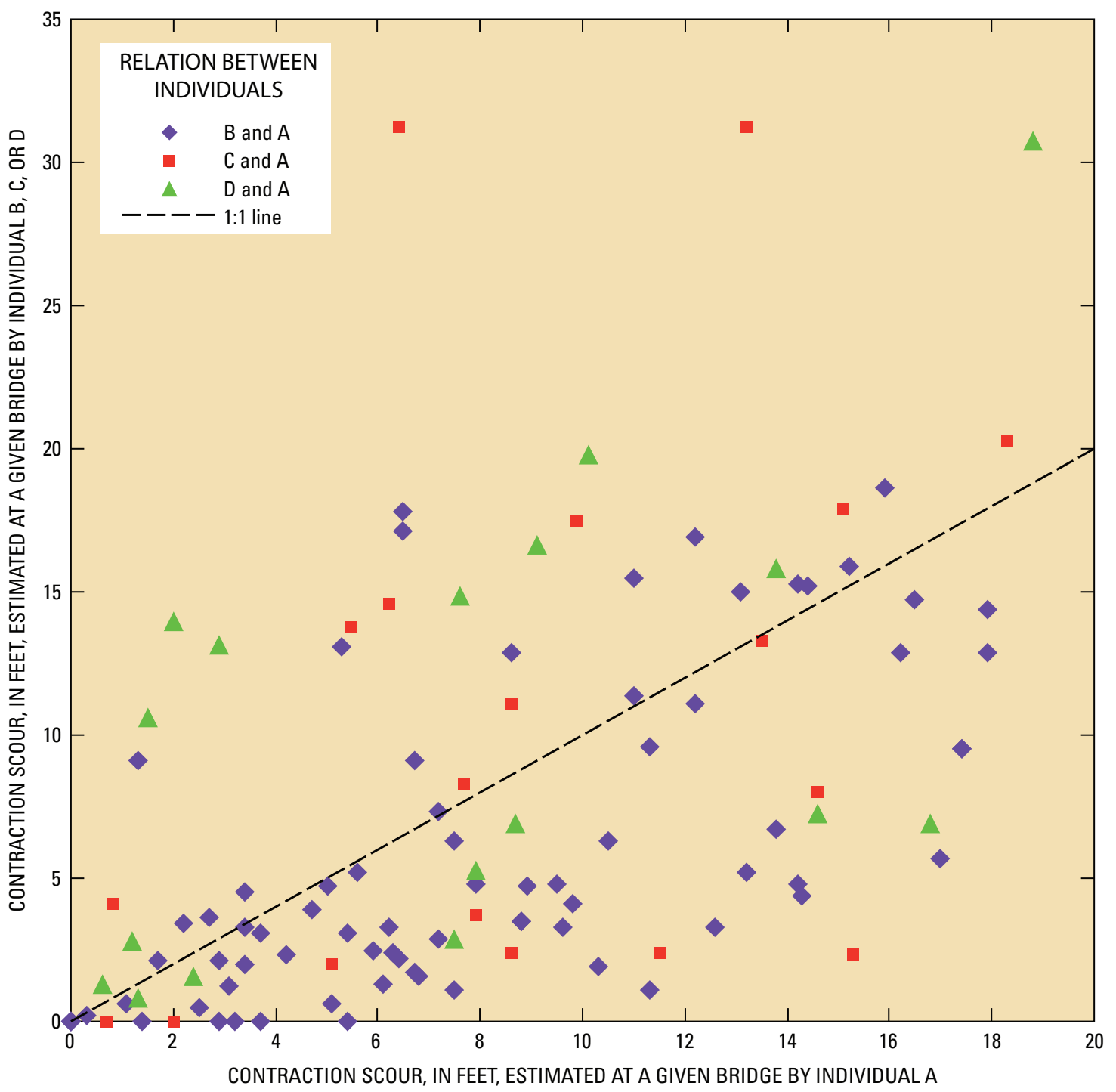

Figure 3. Replicate level-1.5 contraction scour estimates.

As mentioned previously, varying initial assumptions noted on level-1.5 field forms commonly influence agreement among replicate analyses. For example, at some sites, the 100-year $\left(Q_{100}\right)$ and/or 500-year $\left(Q_{500}\right)$ floods may result in road overflow. Unless both replicate analyses independently assumed the same amount of road overflow, the velocity and depth of water through the bridge (and all other parameters affected by these values) can be expected to differ. Differing initial assumptions sometimes also can be emphasized by the mathematics of a scour equation. The first site in Appendix 2 (structure number 06155153) provides an example of this. Different interpretations of the width of the main channel at the approach section by individuals $\mathrm{A}$ ( $W_{1}$ value of 66 feet) and $\mathrm{B}$ ( $W_{1}$ value of 111 feet), factored with the shape of the bridge opening, resulted in an estimated $Q_{500}$ contraction scour $\left(y_{\mathrm{cs}}=6.3\right.$ feet $)$ that was less than the estimated $Q_{100}$ contraction scour ( $y_{\mathrm{cs}}=7.3$ feet) for the analysis by individual B. Even though the overbank flow depths $\left(y_{\text {rob }}\right.$ and $y_{\text {lob }}$ ) were greater for $Q_{500}$ than for $Q_{100}$, their contributions to the contraction scour equation are overshadowed by the large difference in top width of water at the bridge section ( $W_{2}$ values of 50 and 74.4 feet) for individuals $\mathrm{A}$ and $\mathrm{B}$. This means that the component of contraction scour resulting from flow constriction in the main channel decreases more than the scour increases in relation to overbank depths, resulting in contraction scour being lower at $Q_{500}$ than $Q_{100}$. Appendix 2 and figures 3-5 would likely show better agreement among replicates if sites with differing initial assumptions were eliminated. However, differing initial assumptions are likely an unavoidable factor if the replicates are completed in a truly independent manner, and thus are included in Appendix 2. 


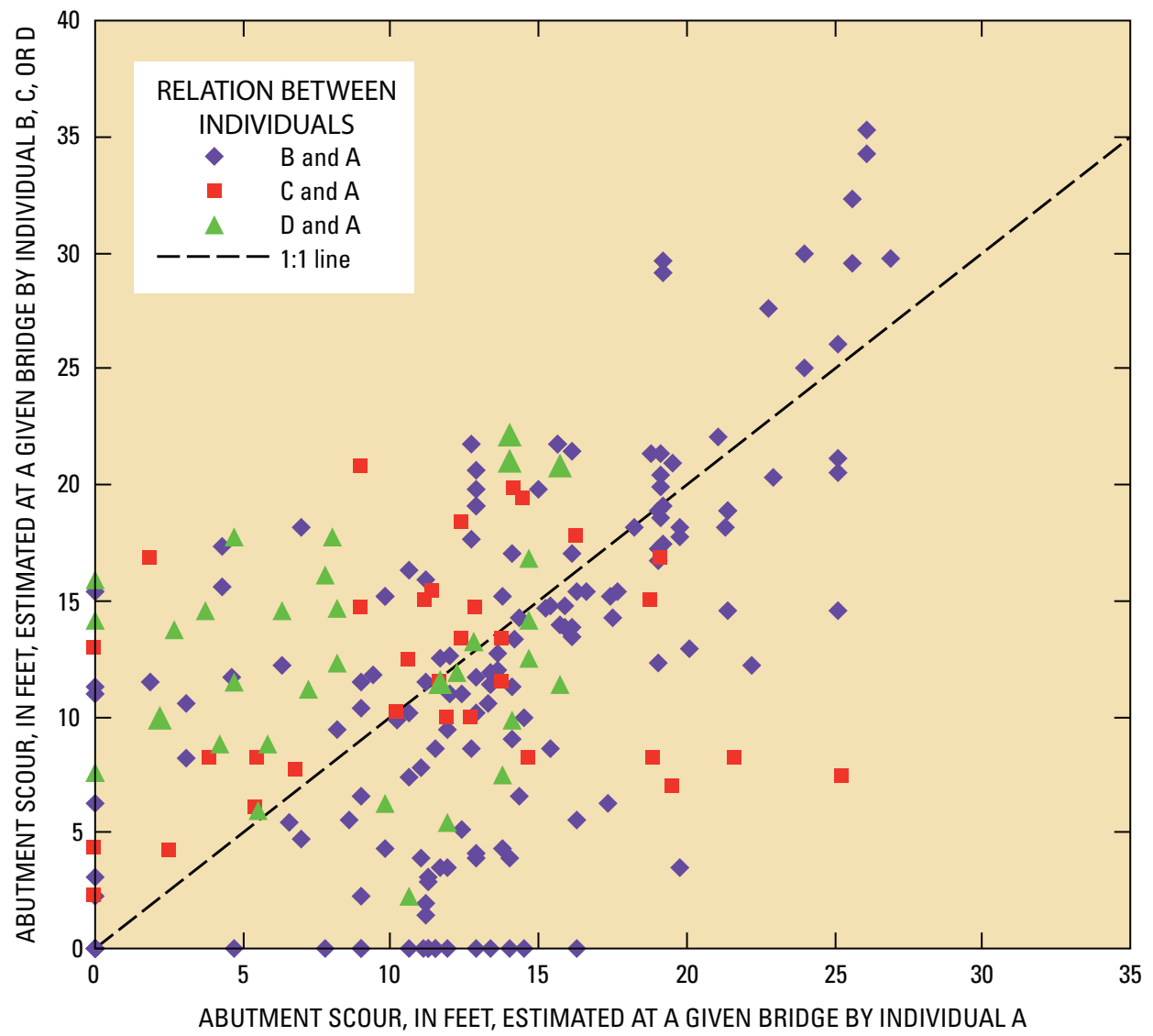

Figure 4. Replicate level-1.5 abutment scour estimates.

\section{Estimated Potential Bridge Scour: Level-2 Method}

A subset of 19 of the 734 bridges with level-1.5 analyses were selected with input from the SDDOT for level-2 scour analyses (fig. 6). Bridges for level-2 analyses were selected to represent the various hydraulic conditions and bridge configurations present across the State. An effort also was made to avoid selecting bridges that were in such a unique setting that it would be difficult to model or represent scour using the standard level-1.5 and level-2 methods.

Level-2 scour analysis involves hydraulic modeling of a segment of the stream containing the bridge to determine the hydraulic variables that are required to solve equations for the varying scour components. The U.S. Army Corps of Engineers Hydraulics Engineering Center has developed a River Analyses System software package (HEC-RAS; Brunner, 2002a, b) to model stream hydraulics. HEC-RAS enables a user to calculate river hydraulic parameters for one-dimensional steady and unsteady flow. The two types of data inputs to HEC-RAS are channel geometry and flows. Channel geometry consists of cross sections and their spacing and also may include structures, such as bridges, weirs, and culverts. Flow data include discharges and boundary conditions. Channel geometry data for level-2 scour analyses were collected by using a total station set up on temporary control points strategically located at each bridge. A total station is an optical surveying instrument that uses electronic distance measuring techniques and radial orientation to determine the horizontal and vertical locations of surveyed points. Flow data include the estimated 100- and 500-year floods as described previously in the section on level-1.5 scour analyses.

HEC-RAS also includes a module for estimating scour at modeled bridges. Although HEC-RAS can internally calculate the required inputs for estimating bridge scour from the hydraulic modeling output, the user can change these inputs if desired. HEC-RAS hydraulic modeling output data were used to populate a series of spreadsheets on which the input parameters were calculated for manual entry into the scour estimation module. This procedure provided greater control of the input parameters. 


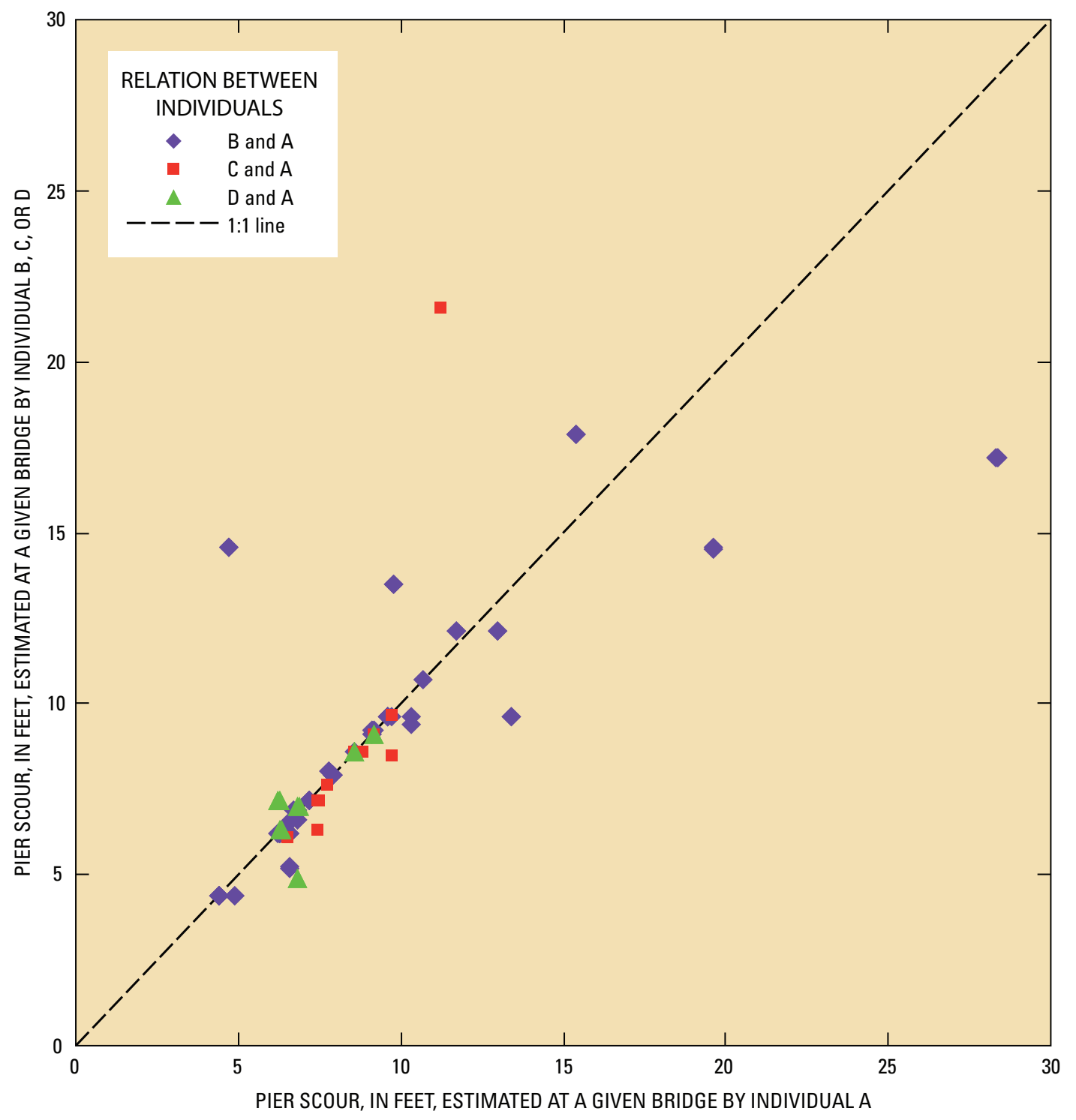

Figure 5. Replicate level-1.5 pier scour estimates.

HEC-RAS software allows the user to select from multiple scour estimation equations in level-2 scour analyses at bridges. For example, abutment scour can be estimated by using either the Froehlich equation or the Hydraulics in the River Environment (HIRE) equation (Richardson, Harrison, and Davis, 1991). The user can select one of these equations or allow HEC-RAS to pick which equation is more applicable on the basis of overbank flow depths. Contraction scour can be calculated with different equations for clear-water scour or live-bed scour conditions, depending on model output of water velocity in the channel. Pier scour can be calculated by using the model output of water velocity at each pier, or the model output of maximum velocity in the channel can be applied to each pier to allow for a worst-case scenario of channel migration.

\section{Comparison of Scour Estimates Between the Level-1.5 and Level-2 Methods}

The performance of the level-1.5 method was assessed by comparing the resulting scour estimates to results from the more rigorous level-2 method at the 19 sites where both methods were used. HEC-RAS was allowed to select the more appropriate contraction scour equation (clear-water or live-bed) and abutment scour equation (Froehlich or HIRE) to enable a better comparison. The maximum channel velocity was applied to all piers in estimating pier scour for the level-2 method. Scour estimates based on the level-1.5 and level-2 methods are shown in table 1 for contraction scour, table 2 for abutment scour, and table 3 for pier scour. 


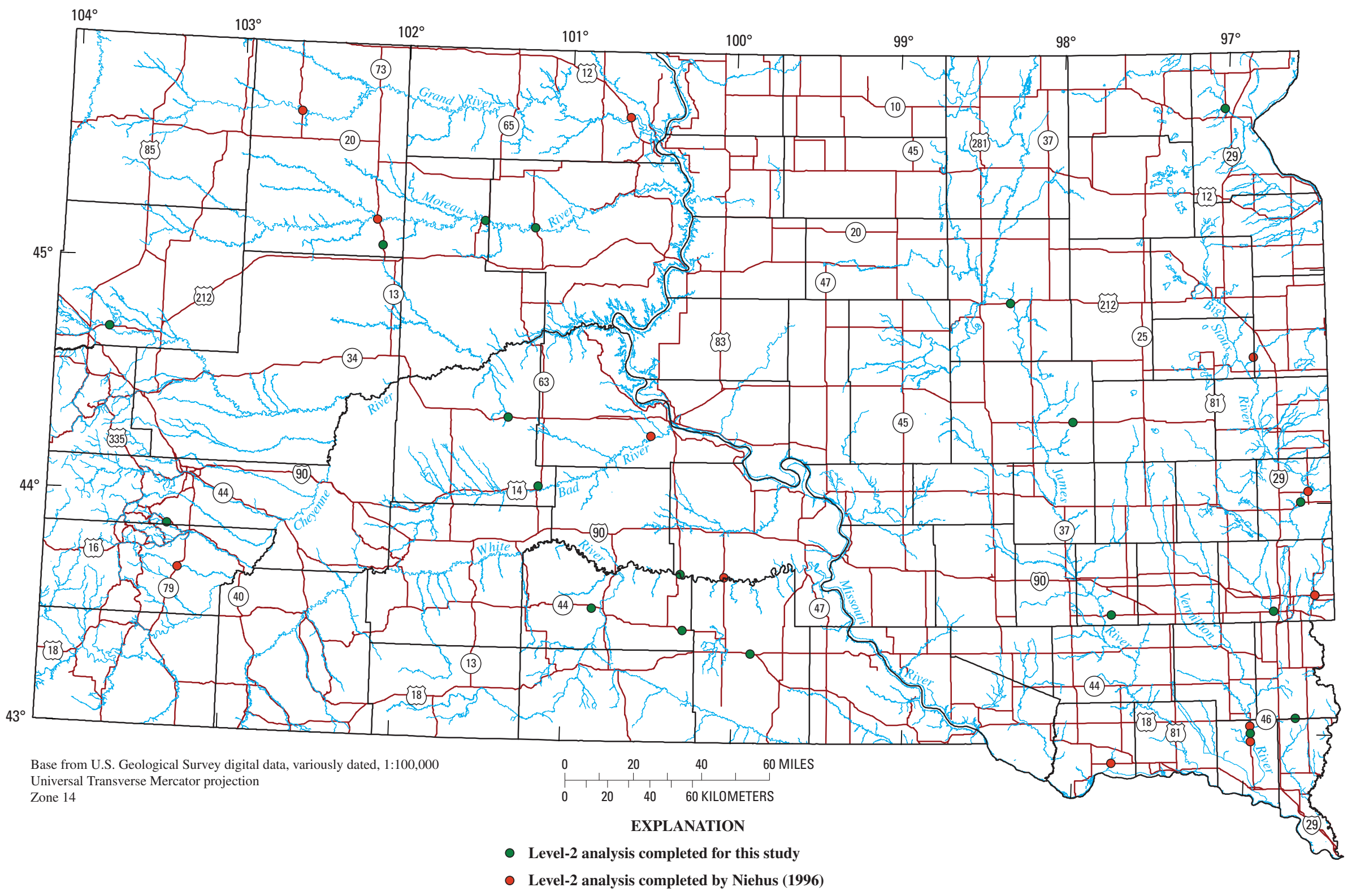

Figure 6. Locations of bridges on State routes in South Dakota with level-2 scour analyses. 
Table 1. Contraction scour estimates from level-1.5 and level-2 analyses, in feet.

$\left[Q_{100}\right.$, estimated discharge with 100-year recurrence interval; $Q_{500}$, estimated discharge with 500-year recurrence interval]

\begin{tabular}{|c|c|c|c|c|}
\hline \multirow{2}{*}{ Site number } & \multicolumn{2}{|c|}{ Level-1.5 analyses } & \multicolumn{2}{|c|}{ Level-2 analyses } \\
\hline & $\mathbf{Q}_{100}$ & $\mathbf{O}_{500}$ & $\mathbf{Q}_{100}$ & $\mathbf{Q}_{500}$ \\
\hline 1 & 2.2 & 2.7 & 0.3 & 0.7 \\
\hline 2 & 2.9 & 3.6 & .3 & 1.6 \\
\hline 3 & 7.0 & 11.3 & .5 & 9.5 \\
\hline 4 & 6.1 & 7.9 & .7 & 3.1 \\
\hline 5 & \multicolumn{4}{|c|}{ Candidate site not selected for analysis. } \\
\hline 6 & 1.5 & 2.8 & .5 & 2.0 \\
\hline 7 & 15.6 & 22.5 & 2.8 & 3.8 \\
\hline 8 & 6.7 & 11.0 & 2.7 & 5.6 \\
\hline 9 & 10.3 & 16.4 & 14.4 & 19.4 \\
\hline 10 & 6.5 & 15.3 & 10.5 & 14.0 \\
\hline 11 & 2.3 & 12.7 & 8.9 & 18.9 \\
\hline 12 & 11.5 & 14.0 & 0 & 0 \\
\hline 13 & 14.2 & 18.8 & 0 & 0 \\
\hline 14 & .4 & 4.5 & .9 & 6.6 \\
\hline 15 & 2.1 & 5.4 & 4.2 & 6.8 \\
\hline 16 & 3.9 & 16.1 & 4.3 & 8.3 \\
\hline 17 & 4.6 & 7.2 & 2.0 & 3.4 \\
\hline 18 & 2.0 & 3.0 & 0 & .6 \\
\hline 19 & 12.0 & 19.6 & 4.5 & 7.9 \\
\hline 20 & 5.8 & 8.1 & 2.6 & 3.7 \\
\hline 21 & \multicolumn{4}{|c|}{ Candidate site not selected for analysis. } \\
\hline 22 & \multicolumn{4}{|c|}{ Candidate site not selected for analysis. } \\
\hline 23 & \multicolumn{4}{|c|}{ Candidate site not selected for analysis. } \\
\hline
\end{tabular}

Table 2. Abutment scour estimates from level-1.5 and level-2 analyses, in feet.

$\left[Q_{100}\right.$, estimated discharge with 100-year recurrence interval; $Q_{500}$, estimated discharge with 500-year recurrence interval]

\begin{tabular}{|c|c|c|c|c|c|c|c|c|}
\hline \multirow{3}{*}{$\begin{array}{c}\text { Site } \\
\text { number }\end{array}$} & \multicolumn{4}{|c|}{ Level-1.5 analyses } & \multicolumn{4}{|c|}{ Level-2 analyses } \\
\hline & \multicolumn{2}{|c|}{$\mathbf{Q}_{100}$} & \multicolumn{2}{|c|}{$\mathbf{Q}_{500}$} & \multicolumn{2}{|c|}{$\mathbf{Q}_{100}$} & \multicolumn{2}{|c|}{$\mathbf{Q}_{500}$} \\
\hline & Left & Right & Left & Right & Left & Right & Left & Right \\
\hline 2 & 0 & 12.0 & 0 & 13.4 & 4.1 & 11.1 & 6.5 & 15.9 \\
\hline 3 & 11.5 & 12.2 & 20.0 & 16.5 & 0 & 15.8 & .8 & 4.7 \\
\hline 4 & 17.3 & 0 & 21.7 & 0 & 1.8 & 0 & 9.7 & 0 \\
\hline 5 & \multicolumn{8}{|c|}{ Candidate site not selected for analysis. } \\
\hline 7 & 13.8 & 20.0 & 17.2 & 23.2 & 10.0 & 24.4 & 10.9 & 31.5 \\
\hline 8 & 11.5 & 11.5 & 13.3 & 13.3 & 1.0 & 0 & 4.1 & 3.5 \\
\hline 9 & 20.0 & 11.5 & 22.6 & 17.9 & 17.2 & 9.1 & 19.0 & 9.3 \\
\hline 10 & 14.0 & 12.0 & 19.5 & 18.6 & 6.1 & 17.6 & 7.1 & 27.1 \\
\hline 11 & 7.0 & 3.1 & 17.5 & 17.7 & 9.6 & 10.0 & 13.0 & 14.5 \\
\hline 12 & 14.6 & 20.3 & 16.7 & 21.5 & 2.6 & 12.6 & 6.9 & 16.7 \\
\hline 17 & 17.3 & 13.8 & 20.2 & 17.9 & 0 & 7.3 & 0 & 12.8 \\
\hline 18 & 11.5 & 11.5 & 13.8 & 13.8 & 5.2 & 3.4 & 8.8 & 16.0 \\
\hline 19 & 8.2 & 8.6 & 12.6 & 12.7 & 9.6 & 10.6 & 7.3 & 10.0 \\
\hline 20 & 14.3 & 20.4 & 17.3 & 21.7 & 12.1 & 0 & 14.4 & 0 \\
\hline 21 & \multicolumn{8}{|c|}{ Candidate site not selected for analysis. } \\
\hline 22 & \multicolumn{8}{|c|}{ Candidate site not selected for analysis. } \\
\hline 23 & \multicolumn{8}{|c|}{ Candidate site not selected for analysis. } \\
\hline
\end{tabular}


Table 3. Pier scour estimates from level-1.5 and level-2 analyses, in feet.

$\left[Q_{100}\right.$, estimated discharge with 100 -year recurrence interval; $Q_{500}$, estimated discharge with 500-year recurrence interval; NA, not applicable (no piers at bridge)]

\begin{tabular}{ccccc}
\hline \multirow{2}{*}{ Site number } & \multicolumn{2}{c}{ Level-1.5 analyses } & \multicolumn{2}{c}{ Level-2 analyses } \\
\cline { 2 - 5 } & $\mathbf{0}_{\mathbf{1 0 0}}$ & $\mathbf{0}_{\mathbf{5 0 0}}$ & $\mathbf{0}_{\mathbf{1 0 0}}$ & $\mathbf{0}_{\mathbf{5 0 0}}$ \\
\hline 1 & 8.5 & 8.5 & 3.8 & 3.9 \\
2 & 10.7 & 10.7 & 9.6 & 10.0 \\
3 & $\mathrm{NA}$ & $\mathrm{NA}$ & $\mathrm{NA}$ & $\mathrm{NA}$ \\
4 & 12.6 & 12.6 & 3.2 & 3.5 \\
5 & Candidate site not selected for analysis. \\
6 & 9.1 & 9.1 & 5.6 & 6.4 \\
7 & 6.7 & 6.7 & 6.5 & 7.5 \\
8 & 8.6 & 8.6 & 5.6 & 5.9 \\
9 & 14.2 & 14.2 & 11.8 & 11.9 \\
10 & 8.6 & 8.6 & 6.0 & 6.0 \\
11 & 8.6 & 8.5 & 6.0 & 6.0 \\
12 & 8.5 & 8.5 & 8.1 & 9.0 \\
13 & 12.9 & 12.9 & 8.5 & 9.0 \\
14 & 6.3 & 6.3 & 5.8 & 6.2 \\
15 & 8.7 & 8.7 & 5.8 & 6.2 \\
16 & 8.0 & 8.0 & 6.6 & 7.3 \\
17 & 8.6 & 8.5 & 6.1 & 6.1 \\
18 & 6.8 & 6.7 & 5.2 & 5.8 \\
19 & 6.3 & 6.3 & 5.0 & 5.6 \\
20 & 20.8 & 20.8 & 18.1 & 19.8 \\
21 & Candidate site not selected for analysis. \\
22 & Candidate site not selected for analysis. \\
23 & Candidate site not selected for analysis. \\
\hline \multicolumn{5}{c}{} \\
\hline \multicolumn{5}{c}{}
\end{tabular}

The envelope curve approach used in the level-1.5 method is designed to overestimate scour relative to the estimate from level-2 scour analyses. As shown in tables $1-3$, this generally is the case. In cases where the level-1.5 method estimated less scour than the level-2 method, the amount of underestimation generally was less than approximately 3 feet. Level- 1.5 estimates of contraction scour, abutment scour, and pier scour were plotted in relation to level-2 estimates (figs. 7-9), which are assumed to be more accurate, to enable graphical comparison. Ideally, points should lie on or above a trend line with a slope of 1 .

Figure 7 shows that the level-1.5 method generally overestimated contraction scour relative to the level-2 method, as intended. In cases of underestimation, the scour depth commonly was within a few feet of the scour depths estimated by the level-2 method. Four level-1.5 values of contraction scour (approximately 10.5 percent) were underestimated by more than 3 feet in comparison to level-2 values.
Figure 8 shows that the level-1.5 method generally overestimated abutment scour relative to the level-2 method, as intended. In cases of underestimation, the scour depth commonly was within approximately 3 feet of the scour depths estimated by the level- 2 method. Nine level- 1.5 values of abutment scour (approximately 11.8 percent) were underestimated by more than 3 feet in comparison to level-2 values.

Figure 9 shows that the level-1.5 method generally overestimated pier scour relative to the level-2 method. Although there is still some scatter, pier scour values tend to cluster much closer to the 1:1 line. The level-1.5 method underestimated pier scour relative to the level-2 method at two sites, but the underestimation was less than 1 foot in both cases.

Although the level-1.5 method is designed to overestimate scour relative to more involved analysis methods, many assumptions, uncertainties, and estimations are involved. If the envelope curves are adjusted such that the level-1.5 method never underestimates relative to the level-2 method, an accompanying result may be excessive overestimation. 


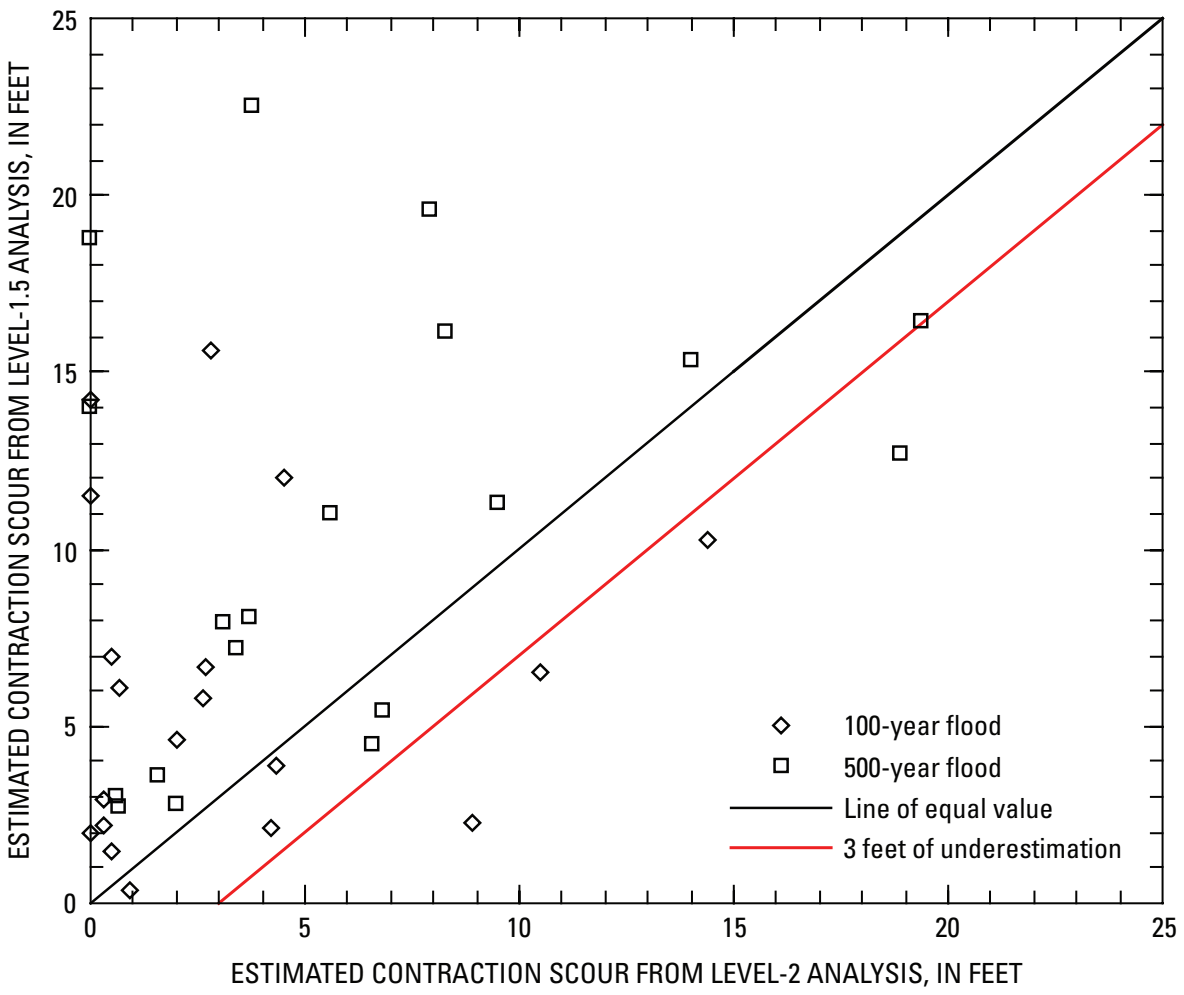

Figure 7. Relation of estimated contraction scour between level-1.5 and level-2 analyses.

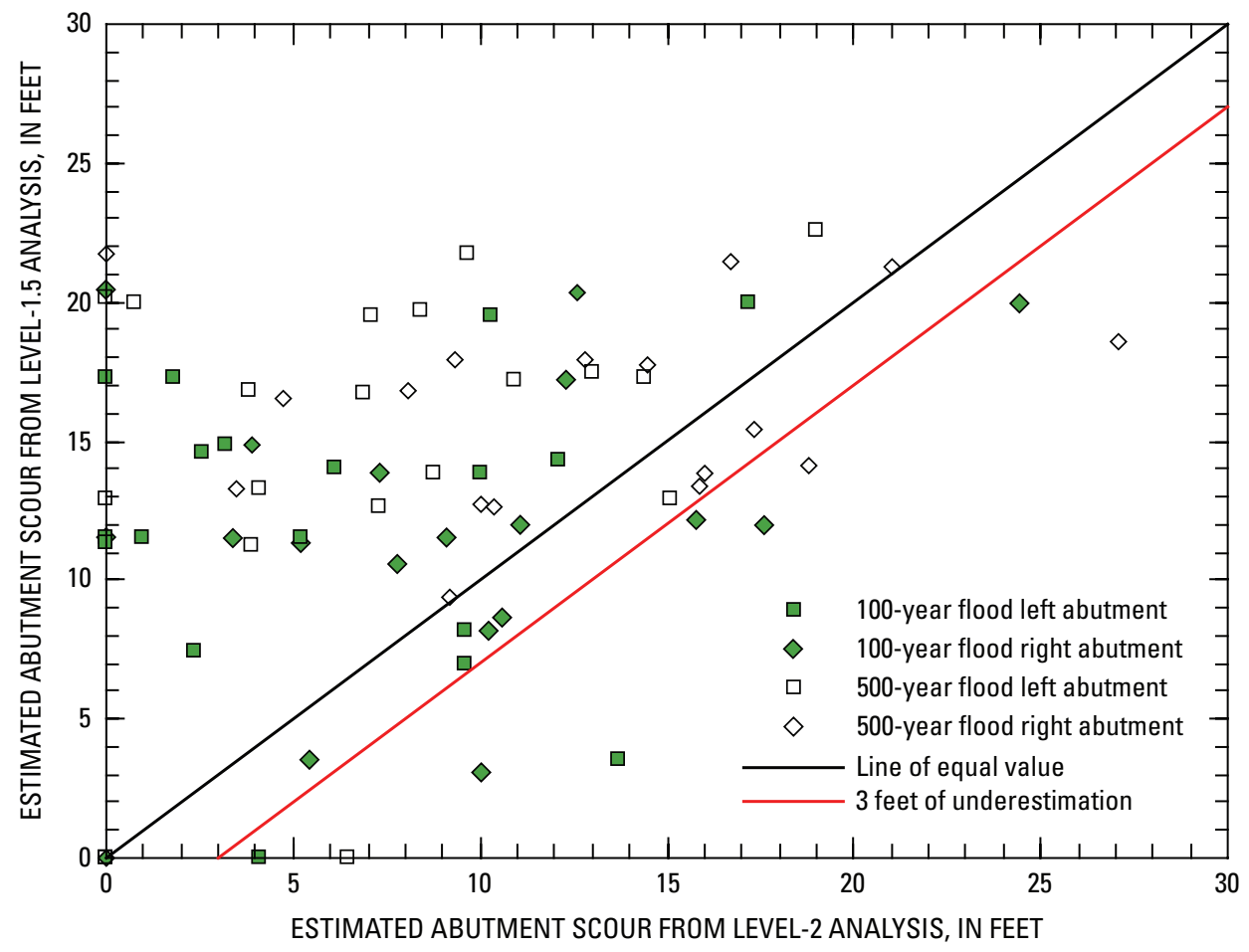

Figure 8. Relation of estimated abutment scour between level-1.5 and level-2 analyses. 


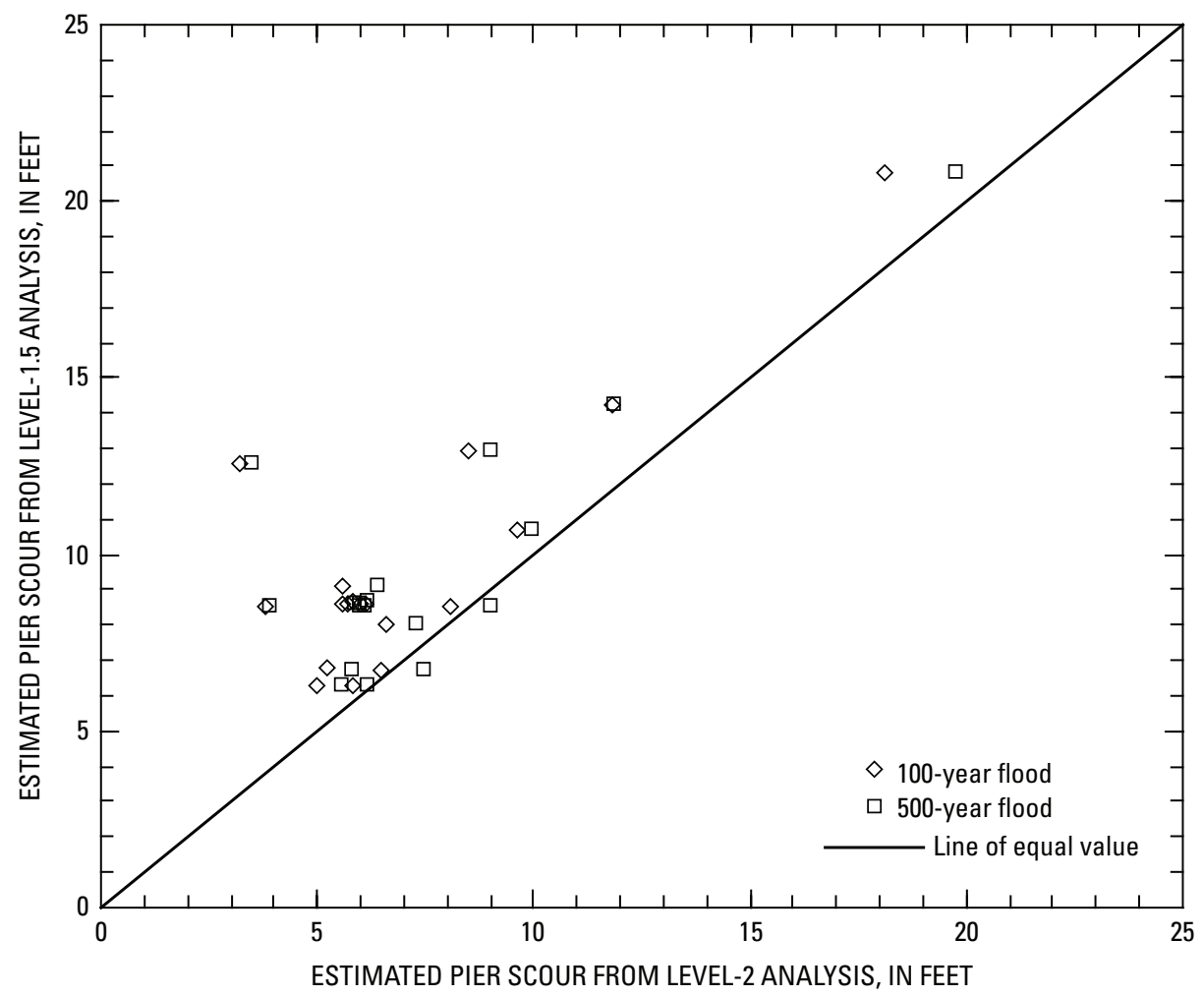

Figure 9. Relation of estimated pier scour between level-1.5 and level-2 analyses.

\section{Assessment of the Suitability of Previously Published Regression Equations to Level-1.5 Scour Analysis in South Dakota}

In developing the level-1.5 method for scour analyses in Montana, Holnbeck and Parrett (1996) developed regression equations to estimate channel velocity and head loss through bridge openings. The velocity regression equation was based on 76 level-2 bridge scour analyses, and the head loss regression equation was based on 72 level-2 bridge scour analyses, all completed in Montana and Colorado. When this study began (2003), the number of level-2 analyses was not sufficient to develop a set of regression equations specific to South Dakota, so the equations established by Holnbeck and Parrett (1996) generally were used. For the James River in eastern South Dakota, channel velocities recorded during streamgaging measurements were known to be substantially less than those calculated by using the regression equation because the river channel has a very low slope. Thus, for level-1.5 sites on the James River, channel velocities sometimes were estimated on the basis of previous velocity measurements instead of the regression equation.

A similar power fit regression of South Dakota data was done to estimate the suitability of the bridge velocity regression equation developed by Holnbeck and Parrett (1996) to conditions in South Dakota. Included were data from the 19 level-2 analyses completed for this study and from 8 of the level-2 analyses completed by Niehus (1996) for which appropriate data could be located (fig. 10). The velocity regression equation from Montana and Colorado data (Holnbeck and Parrett, 1996, p. 40) is

$$
V_{2}=2.07 q_{2}^{0.322}
$$

with an $\mathrm{R}^{2}$ of 0.38 , whereas the regression from South Dakota data is

$$
V_{2}=2.5806 q_{2}^{0.2978}
$$

with an $\mathrm{R}^{2}$ of 0.4271 . This equation developed from South Dakota data produces a greater velocity for a given unit discharge than does the Montana/Colorado equation. 


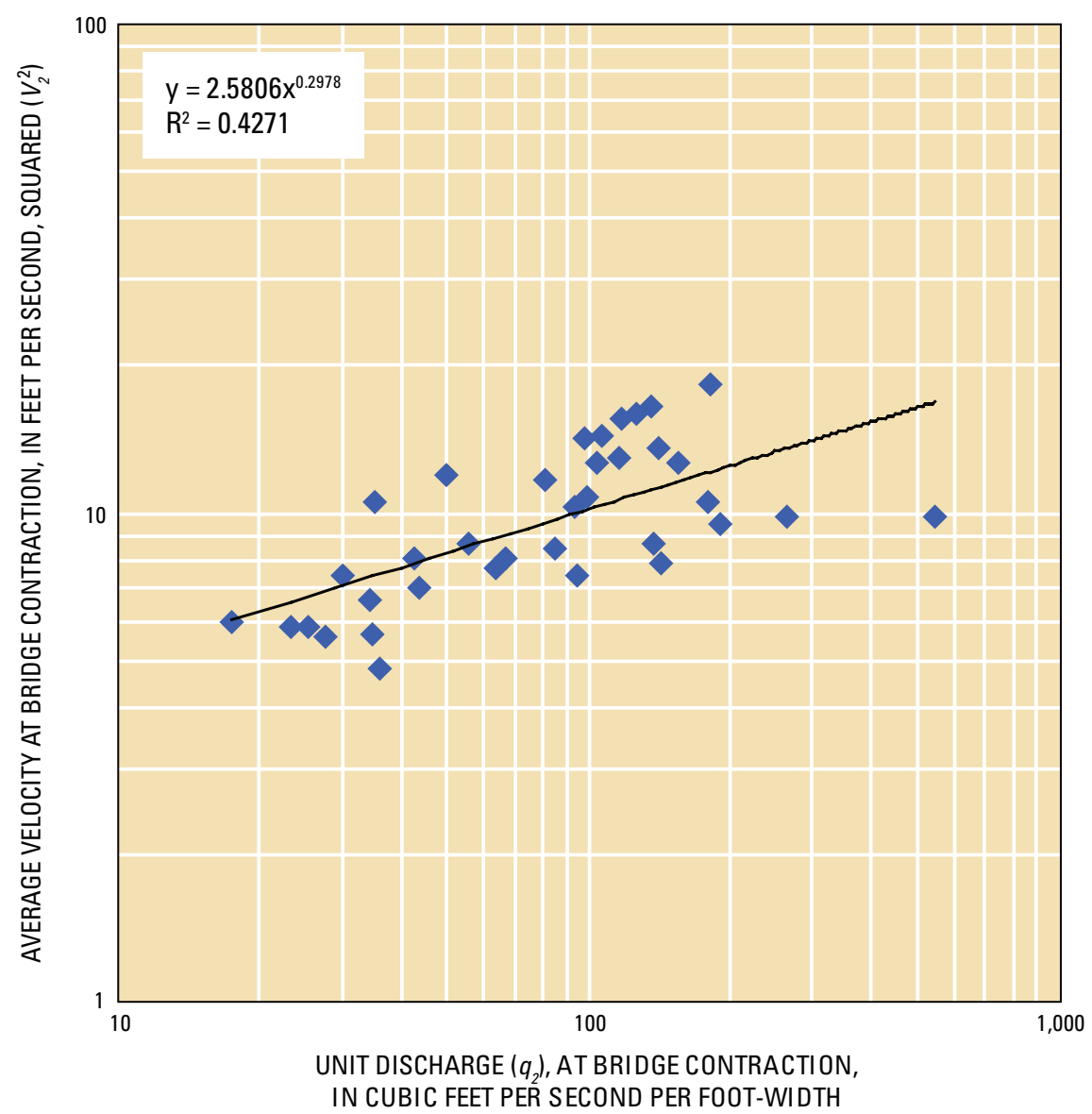

Figure 10. Relation between average velocity squared $\left(V_{2}{ }^{2}\right)$ and unit discharge $\left(q_{2}\right)$ for 19 bridges analyzed for this study and 8 bridges analyzed by Niehus (1996).

A similar comparison was made for head loss though the bridge opening. Figure 11 includes data from the 19 level-2 analyses completed for this study and for 11 sites (fig. 6) with available data published by Niehus (1996). The regression equation for head loss $(\Delta h)$ from Montana and Colorado data (Holnbeck and Parrett, 1996, p. 42) is

$$
\Delta h=0.025 V_{2}^{2}+0.102
$$

with an $\mathrm{R}^{2}$ of 0.59 , whereas the regression equation from the South Dakota data is

$$
\Delta h=0.0186 V_{2}^{2}-0.1650
$$

with an $\mathrm{R}^{2}$ of 0.6255 . For velocities likely to occur during a 100- or 500-year flood, the equation developed from South Dakota data produces smaller head loss for a given velocity compared to the Montana/Colorado regression equation for head loss. But because the regression equation for head loss utilizes the velocity as determined from regression equa- tion 2, the net effects of these two regression equations from South Dakota data need to be evaluated together. For a given unit discharge, the head losses estimated from South Dakota and Montana/Colorado regression equations will be similar. However, the larger velocities produced by the South Dakota regression equation will have the effect of decreasing the overall flow depth at the bridge section. The smaller flow depth will tend to decrease scour, but the larger velocity will tend to increase scour. The net effect on scour estimations may not be large, but the regression equations for velocity and head loss based on South Dakota data could be used for future level-1.5 analyses in South Dakota. Because the Montana/Colorado regression equations for velocity and head loss were each developed using more than twice the amount of data available for South Dakota regression equations, the regression equations from South Dakota data should be reevaluated if additional level-2 analyses become available. 


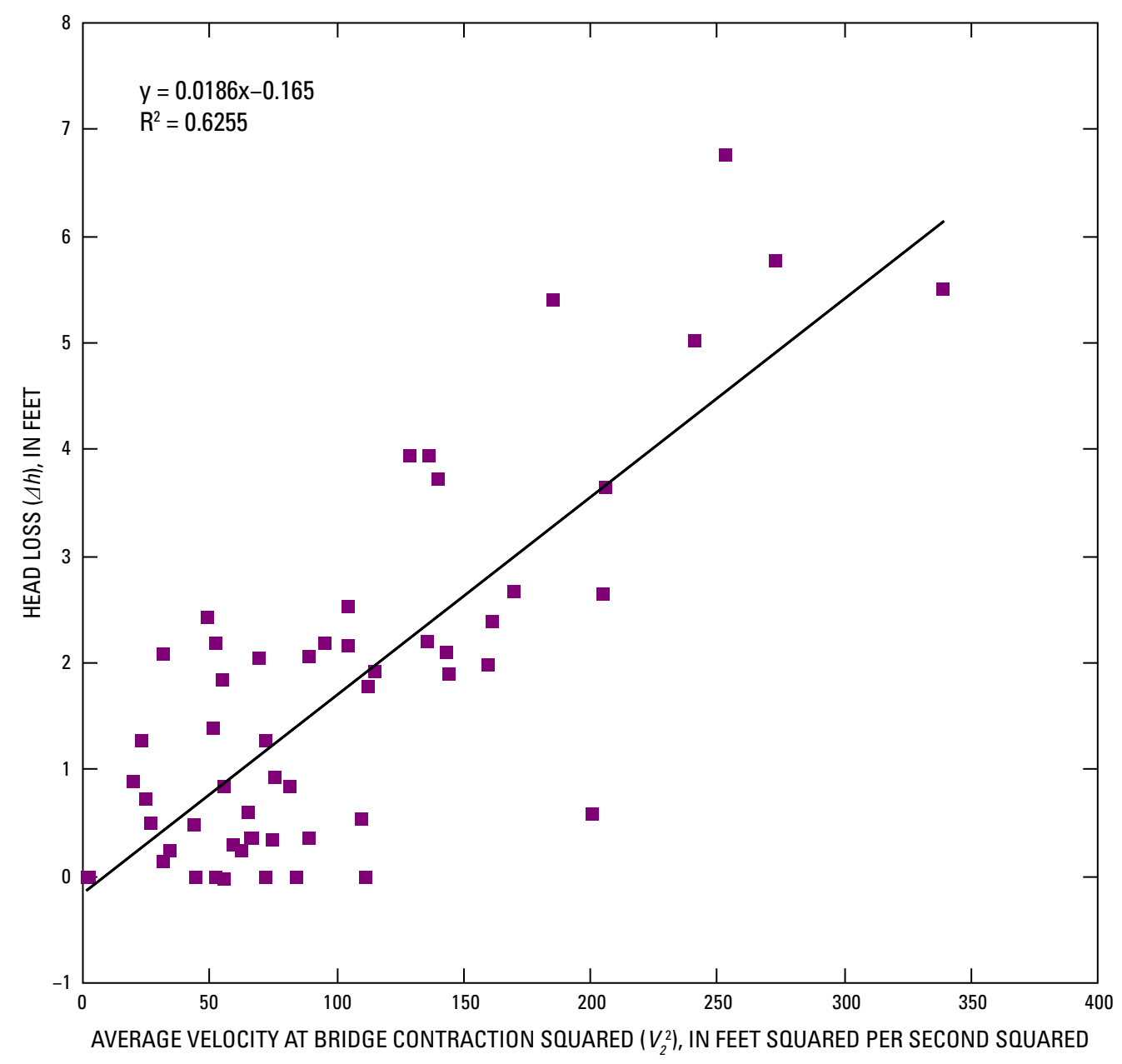

Figure 11. Relation between head loss $(\Delta h)$ through the bridge opening and average velocity squared $\left(V_{2}^{2}\right)$ for bridges analyzed for this study and 11 bridges analyzed by Niehus (1996).

\section{Considerations for Future Estimation of Bridge Scour in South Dakota}

Recent advances in geographic information systems methods and software have resulted in the availability of a new and automated tool for determination of flood magnitudes at various frequencies. StreamStats (Ries and others, 2005) currently (2008) is being implemented for South Dakota and likely will become an important method for determining flood-frequency magnitudes for future level-1.5 and level-2 bridge scour analyses within the State. The flood estimates used during this study can later be compared with estimates from StreamStats, and any substantial differences can be addressed at that time.
As described previously, regression equations developed from level-2 bridge scour analyses in South Dakota for use in estimating velocity and head loss would be beneficial for future level-1.5 analyses in the State. If a sufficient number of additional level- 2 analyses become available, it may be possible to develop basin-specific velocity and head-loss regressions. This may be especially valuable for level-1.5 analyses on the James River because of its very flat gradient and low velocities. 


\section{Summary}

Flowing water can erode (scour) soils and cause structural failure of a bridge by exposing or undermining bridge foundations (abutments and piers). A rapid scour-estimation technique, known as the level-1.5 method and developed by the U.S. Geological Survey, was used to evaluate potential scour at selected bridges in South Dakota in a study conducted during 2003-07 in cooperation with the South Dakota Department of Transportation. This method was used to estimate scour for the 100-year and 500-year floods at 734 bridges over State routes. The 100-year and 500-year floods for each bridge were estimated by using a combination of methods developed for South Dakota. Quality assurance/quality control of the level-1.5 scour estimations was achieved by performing 57 replicate analyses, and differences can be tracked back to one or more different initial assumptions.

Estimated scour depths and other selected information from the level-1.5 field forms are presented in tabular format. Estimates of potential contraction scour at the 734 bridges ranged from 0 to 33.9 feet for the 100-year flood and from 0 to 35.8 feet for the 500-year flood. Abutment scour ranged from 0 to 36.9 feet for the 100-year flood and from 0 to 45.9 feet for the 500-year flood. Pier scour ranged from 0 to 30.8 feet for the 100-year flood and from 0 to 30.7 feet for the 500 -year flood. The scour depths estimated by using the level-1.5 method can be used by the South Dakota Department of Transportation and others to identify bridges that may be susceptible to scour.

Scour at 19 selected bridges also was analyzed by using the level-2 method, and estimated scour depths from the two methods were compared. The U.S. Army Corps of Engineers Hydraulic Engineering Center-River Analysis System (HECRAS) was used for hydraulic modeling and to estimate level-2 bridge scour. Contraction, abutment, and pier scour estimates produced by level-1.5 and level-2 methods are presented in tabular and graphical formats. Compared to the level-2 method, the level-1.5 method generally overestimated scour as designed, or in a few cases slightly underestimated scour. The level-1.5 method underestimated contraction scour by more than 3 feet for approximately 10.5 percent of the analyses and underestimated abutment scour by more than 3 feet for approximately 11.8 percent of the analyses. Pier scour was either overestimated or underestimated by less than 1 foot.

Results of the level-2 analyses for bridges in South Dakota were then used to develop regression equations for change in head and average velocity through bridge contractions. These regression equations derived from South Dakota data were compared to similar regression equations derived from Montana and Colorado data. Future level-1.5 scour investigations in South Dakota may benefit from the use of these South Dakota-specific regression equations for estimating change in head and average velocity at bridges.

\section{References}

Brunner, G.W., 2002a, HEC-RAS, River Analysis System Hydraulic Reference Manual: U.S. Army Corps of Engineers Hydrologic Engineering Center CPD-69, 350 p.

Brunner, G.W., 2002b, HEC-RAS, River Analysis System User's Manual: U.S. Army Corps of Engineers Hydrologic Engineering Center CPD-68, 420 p.

Butch, G.K., 1990, Measurement of bridge scour at selected sites in New York, excluding Long Island: U.S. Geological Survey Water-Resources Investigations Report 90-4083, $17 \mathrm{p}$.

Holnbeck, S.R., and Parrett, C., 1996, Method for rapid estimation of scour at highway bridges based on limited site data: U.S. Geological Survey Water-Resources Investigations Report 96-4310, 79 p.

Niehus, C.A., 1996, Scour assessments and sediment-transport simulation for selected bridge sites in South Dakota: U.S. Geological Survey Water-Resources Investigations Report 96-4075, 80 p.

Richardson, E.V., Harrison, L.J., and Davis, S.R., 1991, Evaluating scour at bridges: U.S. Department of Transportation Publication No. FHWA-IP-90-017, Hydraulic Engineering Circular No. 18 (HEC 18), 105 p.

Ries, Kernell G., III, Steeves, P.A., Coles, J.D., Rea, A.H., and Stewart, D.W., 2005, StreamStats-A U.S. Geological Survey Web application for stream information: U.S. Geological Survey Fact Sheet FS 2004-3115, 4 p., accessed January 10, 2006, at http://md.water.usgs.gov/publications/ fs-2004-3115/.

Sando, S.K., Driscoll, D.G., and Parrett, Charles, 2008, Peak-flow frequency estimates based on data through 2001 for selected streamflow gaging stations in South Dakota: U.S. Geological Survey Scientific Investigations Report 2008-5104, online-only at http://pubs.usgs.gov/ sir/2008/5104/.

Sando, S.K., 1998, Techniques for estimating peak-flow magnitude and frequency relations for South Dakota streams: U.S. Geological Survey Water-Resources Investigations Report 98-4055, 48 p., accessed January 10, 2006, at http://pubs.usgs.gov/wri/wri98-4055/.

U.S. Department of Transportation, 1988, Scour at bridges: Washington, D.C., Federal Highway Administration Technical Advisory T 5140-20, 6 p. 


\section{Appendixes}

Selected information from the level-1.5 analyses of scour at 734 bridges (Appendix 1) and from the level-1.5 replicate analyses of scour at 57 bridges (Appendix 2) in South Dakota were compiled and organized into two Excel spreadsheets (files) that each contain two worksheets. The information worksheets "Readme" contain descriptions of the headings used in the table worksheets.

\section{Appendix 1. Selected Information from the Level-1.5 Analyses of Scour at 734 Bridges in South Dakota (Excel Spreadsheet).}

\section{Appendix 2. Selected Information from the Level-1.5 Replicate Analyses of Scour at 57 Bridges in South Dakota (Excel Spreadsheet).}


Publishing support provided by:

Helena and Denver Publishing Service Centers

For more information concerning this publication, contact: Director, USGS South Dakota Water Science Center 1608 Mountain View Road

Rapid City, SD 57702

(605) 394-3220 


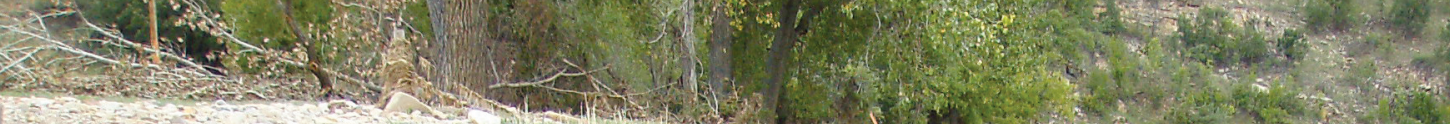

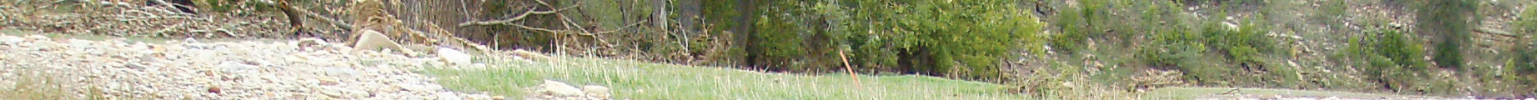

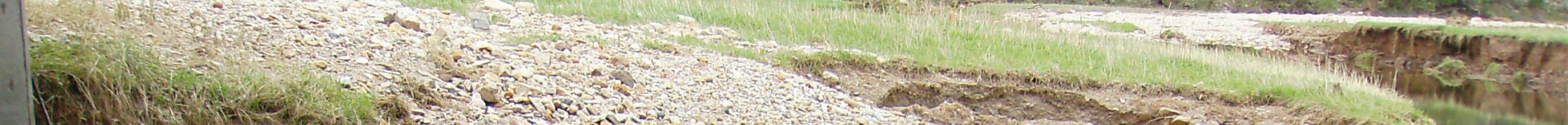

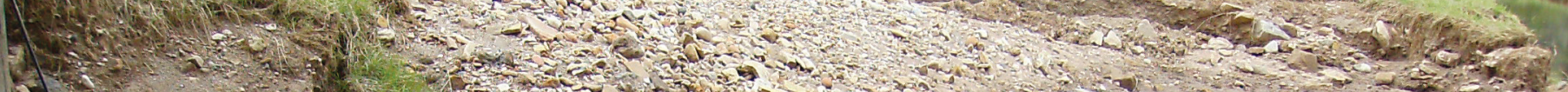
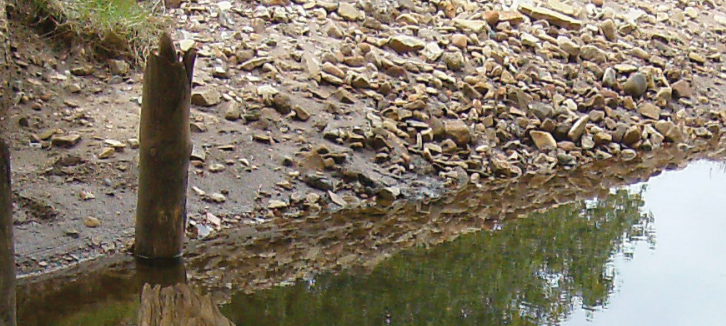

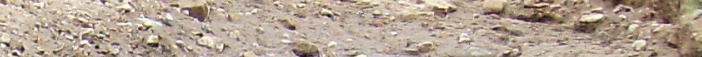

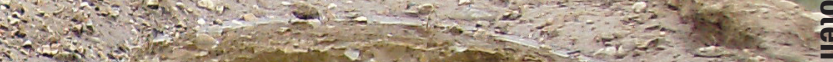

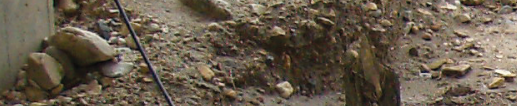

2.3.

(1)

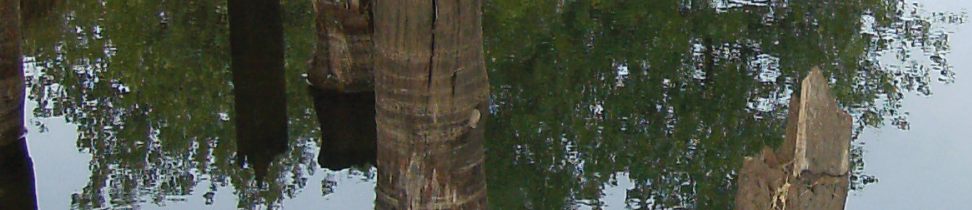

,
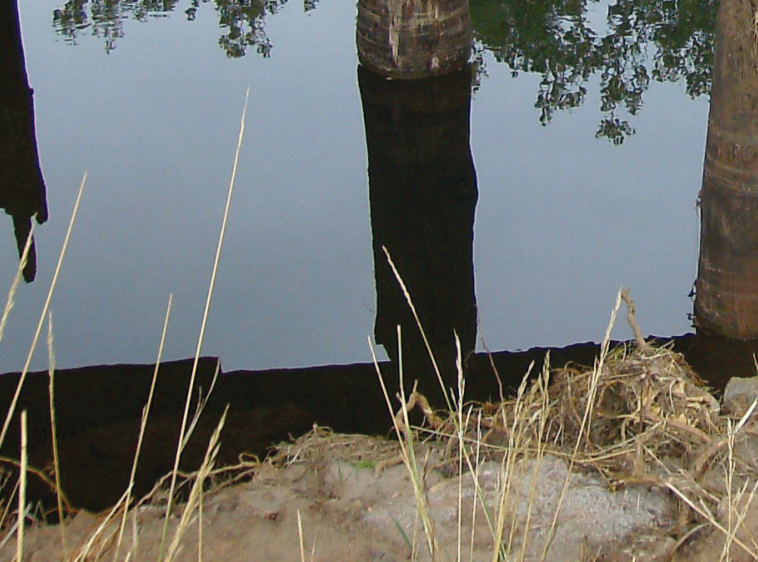

sit

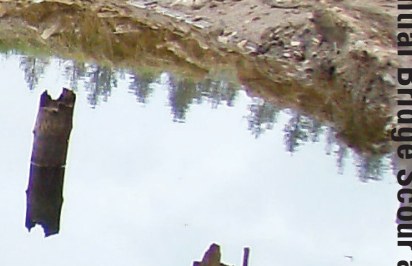

